\title{
CAUSES AND TREATMENT OF DYSCTOCIA IN COWS IN SULAIMANI PROVINCE
}

\author{
TALIB G.M.ALI and FARAIDOON A.S.M.AMIN
} Department of Surgery and Theriogenology, College of Veterinary Medicine, Sulamani University, Sulamani, Kurdistan
Region- Iraq

Received: 28 December 2015; Accepted: 30 January 2016

\begin{abstract}
Atotal of 25 native and cross breed cows from 2011 to 2013 were used to study the common causes and to find a suitable treatment for dystocia. Out of 25 cases of dystocia in cows, $15(60 \%)$ results of maldispositions, $6(24 \%)$ due to fetal abnormalities and $4(16 \%)$ because of fetal emphysema.Calf status classified as; 20 (80\%) was stillbirth and $5(20 \%)$ was a live birth. While for the calf sex, $16(64 \%), 9(36 \%)$ for the male and female calf respectively. The result of the investigation showed that the dystocia in cows was $17(68 \%), 8(32 \%)$ cases related to primiparous and multiparous cows respectively. In the present study the type of treatment which are used in cows suffer from dystocia was 5 (20\%), 4(16\%), 16 (64\%) by manual, fetotomy and cesarean section respectively. Retained placenta, metritis and uterine prolapse are diseases that associated with the dystocia in 13 cows as $8(61.53 \%), 4(30.67 \%)$ and $1(7.69 \%)$ respectively. The mortality rate in dam because of postpartum complications was reached $4(16 \%)$.
\end{abstract}

Key words: Dystocia, Cesarean section, Stillbirth, Treatment, Parity.

\section{INTRODUCTION}

Dystocia or calving difficulty defined as difficult birth or parturition occurs when the first or second stage of labor is prolonged and assistance is required for delivery (Noakes et al., 2009) and the need for increased attention to the loss of the cow and calf (Thompson and Wiltbank, 1983; Haskell 2014). The condition is also associated with a reduction in milk yield in the subsequent lactation and higher culling rate have been observed (Lombard et al., 2007). Dystocia in cows influences the economics of the animal herd through calf loss, poorer subsequent reproductive efficiency of the dam, increased labor or veterinary costs, and occasional cow losses (Roberts, 1986; McDermott et al., 1992). Furthermore, normal parturition is an important economic trait. So calving is a critical time in the cow-calf production cycle, and calving problems (Roberts, 1986). Dystocia and stillbirth can result in direct losses due to calf mortality, dam mortality and premature culling as well as the indirect cost due to additional veterinary services, labor and treatment (Berry et al., 2007). A dairy cow hasresulted in an increased incidence of dystocia, probably due to an increase of body weight of the calf and the change in its shape (Burfening et al., 1979). Dystocia is more frequent in the primiparous heifers and the fetopelvic disproportion

Corresponding author: Dr.TalibG.M.Ali

E-mail address: talib_1960@yahoo.com

Present address: Department of Surgery and Theriogenology,

College of Veterinary Medicine, Sulamani University, Sulamani,

Kurdistan Region- Iraq is the main cause of dystocia, whereas maldisproportions are common in pleuriparous cows (Thomspon et al., 1980). The two determents of fetopelvic disproportions are calf birth weight and maternal pelvic size (Uzmay et al., 2010). The present study was conducted to determine the main causes and to find the suitable treatment for dystociain cows as well astoknow the postpartum diseases which are associated with dystocia in cows.

\section{MATERIALS AND METHODS}

The research was conducted on 25 dairy cows (native andcross breed) suffered from dystocia whereby some of them brought to the Veterinary Teaching Hospital of the College of Veterinary Medicine at the University of Sulaimani, while the other conditions were brought to the veterinary hospitals which are dependant to the Sulaimai Province. The study was carried out from 2011 to 2013.The age of the animals ranged from 2.5- 8 years. The total cases were diagnosed depending on the case history, physical and transvaginal examination. After the causes of dystocia were determined, which was fetal maternal or both causes, the selected proper treatment was done. Some of them were treated by force extraction after correction of abnormal presentation, position, posture of the fetus to the normal through using hands as well as other instruments such as obstetrical ropes and chains with lubricant materials. Partial fetotomy was done in some cases by using the fetotomeinstrument. The uncorrectable cases of dystocia were treated by cesarean section which is 
considered the best fordelivery of the fetus. Cesarean sections performed through the left flank approach as under the local infiltration anesthesia with $2 \%$ lignocain as well as using a set of surgical instruments.

\section{RESULTS}

Table (1) lists the frequency of dystocia detected in 25 cows $15(60 \%)$ native and $10(40 \%)$ cross breed. The most common condition results in fetal dystocia which are classified as follows; $15(60 \%)$ cases due to fetal maldisproportions, $6(24 \%)$ cases because of fetal abnormalities and $4(16 \%)$ cases due to fetal emphysema. Out of 25 cases of dystocia, 20(80\%) were stillbirth, and $5(20 \%)$ were live birthed. While for the calf sex, $16(64 \%)$ and $9(36 \%)$ for the male and female calf respectively. The results of the investigation showed dystocia was associated with the dam parity. Where out of 25 cases were suffering from dystocia, $17(68 \%)$ and $8(32 \%)$ cases were related to primiparous and multiparous cow respectively. In the present study the total treatment of the cases were 5(20\%), 4(16\%) and 16(64\%) in manual, fetotomy and cesarean section respectively. Furthermore the treatment of dystocia inprimiparous revealed that $3(12 \%), 2(8 \%), 12(48 \%)$ for manual, fetotomy and caesarean section respectively. While the treatment of dystocia in multiparous cows was $2(8 \%), 2(8 \%)$ and $4(16 \%)$ for the manual, fetotomy and cesarean section respectively. In the present study the results of calves born revealed that all deliver was single, whereby 16 (64\%) male and $9(36 \%)$ was female calves. In this research a number of postpartum diseasesrelated to dystocia were observed, as $8(61.53 \%), 4(30.67 \%)$ and $1(7.69 \%)$ for the retained fetal membranes, metritis and uterine prolapse respectively as in Table (2). Finally the mortality rate of the cows in this study was reached 4 $(16 \%)$.

Table 1: The major causes and the proper treatment for dystocia in cows.

\begin{tabular}{|c|c|c|c|c|c|c|c|c|c|}
\hline \multirow[b]{2}{*}{ Item } & \multirow[t]{2}{*}{ No.\% } & \multicolumn{2}{|c|}{ Birth status } & \multicolumn{2}{|c|}{ Calf sex } & \multicolumn{3}{|c|}{ Manner delivery or treatment } & \multirow{2}{*}{$\begin{array}{c}\text { Postpartum } \\
\text { mortality } \\
\text { (Cows) No.\% }\end{array}$} \\
\hline & & $\begin{array}{l}\text { Stillbirth } \\
\text { No.\% }\end{array}$ & $\begin{array}{c}\text { Live } \\
\text { Birth } \\
\text { No.\% }\end{array}$ & $\begin{array}{l}\text { Male } \\
\text { No, } \%\end{array}$ & $\begin{array}{l}\text { Female } \\
\text { No. } \%\end{array}$ & $\begin{array}{c}\text { Manual } \\
\text { No. } \%\end{array}$ & $\begin{array}{l}\text { Fetotomy } \\
\text { No.\% }\end{array}$ & $\begin{array}{c}\text { Cesarean } \\
\text { section } \\
\text { No.\% }\end{array}$ & \\
\hline Fetal dystocia & \multirow{2}{*}{$\begin{array}{c}15 \\
(60 \%)\end{array}$} & \multirow{2}{*}{$\begin{array}{c}10 \\
(20 \%)\end{array}$} & \multirow{2}{*}{$\begin{array}{c}5 \\
(20 \%)\end{array}$} & \multirow{2}{*}{$\begin{array}{c}9 \\
(36 \%)\end{array}$} & \multirow{2}{*}{$\begin{array}{c}6 \\
(24 \%)\end{array}$} & \multirow{2}{*}{$\begin{array}{c}4 \\
(16 \%)\end{array}$} & \multirow{2}{*}{$\begin{array}{c}3 \\
(12 \%)\end{array}$} & \multirow{2}{*}{$\begin{array}{c}8 \\
(32 \%)\end{array}$} & \multirow{2}{*}{$\begin{array}{c}2 \\
(8 \%)\end{array}$} \\
\hline $\begin{array}{c}\text { Fetal } \\
\text { maldispositions }\end{array}$ & & & & & & & & & \\
\hline $\begin{array}{c}\text { *Fetal } \\
\text { abnormalities } \\
\end{array}$ & $\begin{array}{c}6 \\
(24 \%) \\
\end{array}$ & $\begin{array}{c}6 \\
(24 \%) \\
\end{array}$ & --- & $\begin{array}{c}4 \\
(16 \%) \\
\end{array}$ & $\begin{array}{c}2 \\
(8 \%) \\
\end{array}$ & $\begin{array}{c}1 \\
(4 \%) \\
\end{array}$ & $\begin{array}{c}1 \\
(4 \%) \\
\end{array}$ & $\begin{array}{c}4 \\
(16 \%) \\
\end{array}$ & $\begin{array}{c}1 \\
(4 \%) \\
\end{array}$ \\
\hline $\begin{array}{c}\text { *Fetal } \\
\text { emphysema }\end{array}$ & $\begin{array}{c}4 \\
(16 \%) \\
\end{array}$ & $\begin{array}{c}4 \\
(16 \%) \\
\end{array}$ & $-\cdots--$ & $\begin{array}{c}3 \\
(12 \%) \\
\end{array}$ & $\begin{array}{c}1 \\
(4 \%)\end{array}$ & $-\cdots-\cdot$ & ---- & $\begin{array}{c}4 \\
(16 \%) \\
\end{array}$ & $\begin{array}{c}1 \\
(4 \%)\end{array}$ \\
\hline Total & $\begin{array}{c}25 \\
(100 \%)\end{array}$ & $\begin{array}{c}20 \\
(\mathbf{8 0 \%})\end{array}$ & $\begin{array}{c}5 \\
(20 \%) \\
\end{array}$ & $\begin{array}{c}16 \\
(64 \%)\end{array}$ & $\begin{array}{c}9 \\
(36 \%)\end{array}$ & $\begin{array}{c}5 \\
(20 \%)\end{array}$ & $\begin{array}{c}4 \\
(16 \%)\end{array}$ & $\begin{array}{c}16 \\
(64 \%)\end{array}$ & $\begin{array}{c}4 \\
(16 \%)\end{array}$ \\
\hline Dam parity & \multirow[t]{2}{*}{$\begin{array}{c}17 \\
(68 \%)\end{array}$} & \multirow[t]{2}{*}{$\begin{array}{c}14 \\
(54 \%)\end{array}$} & \multirow[t]{2}{*}{$\begin{array}{c}3 \\
(12 \%)\end{array}$} & \multirow[t]{2}{*}{$\begin{array}{c}10 \\
(40 \%)\end{array}$} & \multirow[t]{2}{*}{$\begin{array}{c}7 \\
(28 \%)\end{array}$} & \multirow[t]{2}{*}{$\begin{array}{c}3 \\
(12 \%)\end{array}$} & \multirow[t]{2}{*}{$\begin{array}{c}2 \\
(8 \%)\end{array}$} & \multirow[t]{2}{*}{$\begin{array}{c}12 \\
(48 \%)\end{array}$} & \multirow[t]{2}{*}{$\begin{array}{c}2 \\
(8 \%)\end{array}$} \\
\hline *Primiparous & & & & & & & & & \\
\hline *Multiparous & $\begin{array}{c}8 \\
(32 \%)\end{array}$ & $\begin{array}{c}6 \\
(24 \%)\end{array}$ & $\begin{array}{c}2 \\
(8 \%)\end{array}$ & $\begin{array}{c}6 \\
(24 \%)\end{array}$ & $\begin{array}{c}2 \\
(8 \%)\end{array}$ & $\begin{array}{c}2 \\
(8 \%)\end{array}$ & $\begin{array}{c}2 \\
(8 \%)\end{array}$ & $\begin{array}{c}4 \\
(16 \%)\end{array}$ & $\begin{array}{c}2 \\
(8 \%)\end{array}$ \\
\hline Total & $\begin{array}{c}25 \\
(100)\end{array}$ & $\begin{array}{c}20 \\
(\mathbf{8 0 \%}) \\
\end{array}$ & $\begin{array}{c}5 \\
(20 \%) \\
\end{array}$ & $\begin{array}{c}16 \\
(64 \%) \\
\end{array}$ & $\begin{array}{c}9 \\
(36 \%) \\
\end{array}$ & $\begin{array}{c}5 \\
(20 \%) \\
\end{array}$ & $\begin{array}{c}4 \\
(16 \%) \\
\end{array}$ & $\begin{array}{c}16 \\
(64 \%) \\
\end{array}$ & $\begin{array}{c}4 \\
(16 \%) \\
\end{array}$ \\
\hline \multicolumn{10}{|l|}{ Calves born } \\
\hline \multicolumn{10}{|l|}{ *Twins } \\
\hline *Singles & $25(100 \%)$ & $20(80 \%)$ & $5(20 \%)$ & $16(64 \%)$ & $9(36 \%)$ & $5(20 \%)$ & $4(16 \%)$ & $16(64 \%)$ & $4(16 \%)$ \\
\hline Total & $25(100 \%)$ & $20(80 \%)$ & $5(20 \%)$ & $16(64 \%)$ & $9(36 \%)$ & $5(20 \%)$ & $4(16 \%)$ & $16(64 \%)$ & $4(16 \%)$ \\
\hline
\end{tabular}

Table 2: Postpartum diseases after treatment of dystocia in cows.

\begin{tabular}{cc}
\hline Item & No. \% \\
\hline Retained fetal membranes & $8(61.53 \%)$ \\
\hline Metritis & $4(30.67 \%)$ \\
\hline Uterine prolapse & $1(7.69 \%)$ \\
\hline Total & $13(100 \%)$ \\
\hline
\end{tabular}




\section{DISCUSSION}

The general causes of dystocia in cows are fetal attitude, fetal - maternal size mismatch and maternal related cause (Roberts, 1986, Arthur et al., 1988,). In the present study the major cause of dystocia was results of fetal cases which was fetal maldispositions $15(60 \%)$, fetal abnormalities 6(24\%) and fetal emphysema 4(16\%) were common. Sloss (1974a), Uzmay et al. (2010), recorded similar observation. Stillbirth is a calf that born dead, the percentage of the cases reaches $20(80 \%)$ from the total birth status as in Table (1), and the result is lower than that of Citek et al. (2011) which was 180(70.31\%) and higher than the rate of Lombard et al. (2007) which was $8.2 \%$. Stillborn incidence for all calves increased significantly with increasing dystocia scores (Lombard et al., 2007; Adamec et al., 2006).

Alternatively indicates that stillbirth in dairy cattle is increasing and may have a genetic component (Steinbock et al., 2003; Adamec et al., 2006). In addition, calves born during winter were at decreased odds of stillbirth than calves born during autumn (Berger et al., 1992) and this agree with the suggestion of Meyer et al. (2001) in which they found stillbirths were increased during summer compared with winter. These results were expected because the dystocia makes calves more prone to hypothermia and increased odds of death (Azzum et al., 1993). The incidence of dystocia in cows tended to be higher with male than female calves, $16(64 \%)$ vs. $9(36 \%)$ as shown in Table 1 . These results are higher than the incidence recorded by Philipson, (1976), Sieber et al. (1989), McDermott et al.(1992), Johanson and Berger (2003), Phocas and Laloe, (2003), Ettema and Santos (2004) and Gaafar et al. (2011) and Atashi et al. (2012). Where they reported that male born calves on average, weight more than female calves and caused a mismatch of fetal maternal size, which lead to increased chance of dystocia and greater mortality, especially in primiparous dams. A heifer that calves 2 years of age are more likely to experience difficult birth than that of 3 years because they have smaller pelvic areas (Laster et al., 1973).

In this study another cause of dystocia in cows was recorded to be related to fetus. The percentages of fetal abnormalities and fetal emphysema were 6(24\%) and $4(16 \%)$ respectively. These percentages are nearly similar to that observed by Sloss, (1974a); Youngquist and Shore, (1997), Zhang et al. (1999), Citek et al. (2011) and Tripathi et al. (2014). As they reported, the fetal origins of dystocia in cattle can be divided into those caused by excessive fetal size relative to the maternal pelvis (fetopelvic disproportion) and those caused by abnormalities of the fetal attitude. Fetal emphysema should always be suspected in prolonged cases of dystocia exceeding $24 \mathrm{~h}$ which are associated with decomposition or decay of the fetus and accumulation of gases in the subcutaneous tissue (Smith et al., 1976; Purohit and Mehta, 2006). Different methods are used for the treatment of dystocia in cows in this study. It is important to give a set of indications for methods applicable to all the possible obstetrical conditions.

The proportion of calving that required assistance throughout correction and the traction (mutation) in this study was $5(20 \%)$ followed by $4(16 \%)$ and $16(64 \%)$ for the fetotomy and caesarean section respectively. The percentage rate of manual delivery in cows, in the present study was lower than $7.78 \%$, $43.78 \%$ and $48.4 \%$ as mentioned by Arthur et al. (1988); Goyache and Gutierrez (2001) and Citek et al. (2011) respectively. Dufour et al. (1981), Roberts, (1986) and Cook et al. (1993) they referred that the major cases of bovine dystocia, resulting of fetal maldisposition. The incidence of calving that required for assistance was large, especially for primiparous dams in which more than $50 \%$ need assistance at delivery (Lombard et al., 2007; Mee et al., 2011).

In addition primiparous cows were most often affected, management should ensure heifers are inseminated at the proper age and body weight, and considered selecting potential sires (Sieber et al., 1989; Berry et al., 2007 and Zaborski et al., 2009). Fetotomy have a percentage of $4(16 \%)$ as recorded in this study. It is lower than the percentage of Sloss (1974) which was $16.6 \%$ and Buchoo et al. (2008) which was $7.69 \%$. Based on the results of the study, it appears that the treatment of dystocia in cows by cesarean section was more way recorded which were $16(64 \%)$ and lower than Goyache and Gutierrez, (2001) which was $1.9 \%$. The goals of cesarean section are preserved of the dam and calf and the future reproductive efficiency of the dam. The outcome of the cesarean section is a self-fulfilling prophecy (Newman and Anderson, 2005). The choice of fetotomy or cesarean section has always been a controversial subject (Sloss, 1974b; Campbell and Fubini, 1990). Wehrend et al. (2002) revealed that the fetotomy were done because the dystocia results due to incorrect of maldispositions, fetus become stuck during delivery.

The operation is a protracted and exhausting operation, including a wide range of expensive instruments. It may result in damage to the uterine wall, postoperative complications, sepsis and prolong after treatment (Dehghani and Ferguson 1982, Barkema et al., 1992, Vaughan and Mulville, 1995). Results in Table (1) revealed that the effect of parity on the percentage of dystocia in cows, showed varied results from $17(68 \%)$ to $8(32 \%)$ in primiparous and multiparous dam respectively. These results are in accordance with those obtained by Quass et al. (1988) and Eriksson et al. (2004) they found that the frequencies of difficult calving and stillbirth were $6 \%$ of first parity and 1-2\% at later parities in cattle. The result of this study showed 25 cases of dystocia in cows associated with single born calves. Menissier, 
(1982) reported that the dystocia in double muscle cows is caused by modifying calf morphology. Thus, cesarean deliveries are required for $89.5 \%$ of the parturition in Belgian Blue cows (Fiems et al., 2001). Oversize fetuses cannot be delivered normally and therefore, the decision to relieve dystocia either by fetotomy or cesarean delivery would depend on the condition of the fetus and/or the dam. An attempt can be made to remove dead fetal maldispositons and oversized fetuses in a relaxed birth canal by fetotomy but if this fails, cesarean section is the last resort (Purohit and Mehta. 2006). Postpartum diseases that associated with dystocia as in Table 2, the percentages of the diseases was $8(61.53 \%)$, $4(30.76 \%)$ and $1(7.69 \%)$ for the retained placenta, metritis and uterine prolapse respectively. The percentage of retained placenta reaches $8(61.53 \%)$, and the result is higher than the rate of Joosten et al. (1987), Heringstad et al. (2007) and Steinkbock et al. (2003) which was $6.6 \%, 2.7 \%$ and $3.9 \%$, respectively, and also higher than $22 \%$, and $9.5 \%$ as reported by Geverkci et al. (2006) and McClinktock, (2004) respectively.

The incidence of retained placenta in dairy cows in related to individual animal level and farm management factors such, feed quality, time of parturition, farm type, farm size, and housing system (Islam et al., 2013). Stillbirth, difficult calving, fetotomy and cesarean section are caused increase a marked in the rate of retained placenta in dairy cattle. Metritis frequently occurs soon after calving and may severely comprise reproductive performance (Fourichon et al., 2000).

Toxic puerperal metritis or septic metritis occurs with first 10 days after parturition (Sheldon et al., 2006). In addition to bacterial causes, various risk factors related to management and individual cows are associated with uterine infection, including retained placenta, which increase the risk of metritis (Sandal et al., 1979; Torres et al., 1997, Hafez and Hafez, 2000, LeBlanc et al., 2000, Kaczmarowski et al., 2003), and postpartum uterine infection commonly occurs in cows as a sequel to dystocia (Markusfeld, 1987; Kanneene and Miller, 1994, Lewis, 1997, Bearden et al., 2004). Lweis, (1997) and Galvao, (2013) they found that first calf heifers are at higher risk for uterine diseases during dystocia, stillbirth and prolapsed uterus. Finally, the results of the study revealed that the percentage of maternal death was reaches $4(16 \%)$ forprimiparous and multiparous cow. This percentage is lower to that reported by (Sloss, 1974b). In general, the major causes of the death due to trauma of the pelvic organs when traction was applied, and irreversible damage to the pelvic nerves occurred frequently. As well as complicating factors such as paraplegia, sever septicemia and toxemia especially during cesarean section (Roberts, 1986; Newman and Anderson, 2005, Drillich, 2006).

\section{REFERENCE}

Adamec, V.; Cassell, B.G.; Smith, E.P. and Pearson, R.E. (2006): Effect of inbreeding in the dam on dystocia and stillbirths in US Holsteins. J. Dairy. Sci. 89:307-314.

Arthur, P.F.; Makarechian, M. and Price, M.A. (1988): Incidence of dystocia and perinatal calf mortalitity resulting from reciprocal crossing of double muscled and normal cattle. Can. Vet. J. 29:163-167.

Atashi, H.; Abdolmohammadi, A.; Dadpasand, M. and Assadi, A. (2012): Prevalence, risk factors and consequent effect of dystocia in Holstein dairy cows in Iran. Asian- Aust. J. Anim. Sci. 25:4:447-451.

Azzum, S.M.; Kinder, J.S.; Nielsen, M.K.; Werth, L.A.; Gregory, K.E.; Cundiff, L.V. and Koch, R.M. (1993): Environmental effects on neonatal mortality of beef calves. J. Anim. Sci. 71:282-290.

Barkema, H.; Schukken, Y.; Gard, C.; Brand, A. and van der Weygen, G. (1992): Cesarean section in dairy cattle: a study of risk factors. Theriogenology. 37: 489-506.

Bearden, H.J.; Fuquay, J.W. and Willard, S.T. (2004): Applied Animal Reproduction. $6^{\text {th }} \mathrm{Ed}$, Upper saddle River, USA.

Berger, P.J.; Cubas,A.C.; Koehler, K.J. and Healey, M.H. (1992): Factors affecting dystocia and early calf mortality in Angus cows and heifers. J. Anim. Sci. 70: 1775-1788.

Berry, D.P.; Lee, J.M.; Macdonal, K.A. and Roche, J.R. (2007): Body condition score and body weight effects on dystocia and stillbirth and consequent effects on post calving performance. J. Dairy. Sci. 90: 4201- 4211.

Buchoo, B.A.; Bhattacharyya, A. and Fazili, M.R. (2008): A field study on the incidence of dystocia in cattle. Indian. V. J. 85: 1342-1343.

Burffering, P.J.; Kress, D.D.; Friedrich, R.L. and Variman, D. (1979): Ranking sires for calving ease. J. Anim. Sci. 48:2:293-297.

Campbell, M. and Fubini, S. (1990): Indications and surgical approaches for cesarean section in cattl. Comp. Cont. Educ. 12:285-291.

Citek, J.; Hardecka, E.; Rehout, V. and Hanusova, L. (2011): Obstetrical problems and stillbirth in beef cattle. J. Anim. Sci. 29:2:109-118.

Cook, B.R.; Tess, M.W. and Kress, D. D. (1993): Effects of selection strategies using heifers pelvic area and sire birth weight expected progeny differences on dystocia in first calf heifers. J. Anim. Sci. 71: 602- 607.

Dehghani, S. and Ferguson, J. (1982): Cesarean section in cattle: Complications. Comp. Cont. Educ. 4: 387-392.

Drillich, M. (2006): An update on uterine infections in dairy cattle. Slov. Vet. Res., 43: 5-11. 
Dufour, J.J.; Fahmy, M.H. and Roy, G.L. (1981): The influence of pelvic opening and calf size on calving difficulties of beef and dairy crossbred cows. Can. J. Anim. Sci., 61: 279-288.

Erriksson, S.; Nasholm, A.; Johansson, K. and Philipsson, J. (2004): Genetic parameters for calving difficulty, stillrbirth, and birth weight for Hereford and Charolais at first and later parities. J. Anim. Sci. 82: 375-383.

Ettema, J.F. and Santos, J.E.P. (2004): Impact of age at calving on lactation, reproduction, health, and income in first-parity Holsteins on commercial farms. J. Dairy. Sci. 87: 27302742.

Fiems, L.O.; de Campeneer, W.; Caelenbergh, V. and Bougue, C.V. (2001): Relashing ship between dam and calf characteristic with regard to dystocia in Belgian Blue double muscle cows. Anim. Sci. 72:389-394.

Fourichon, C.; Seegers, H. and MaLher, X. (2000). Effect of disease on reproductive in dairy cow: a meta - analysis. Theriogenology, 53: 17291759.

Gaafar, H.M.A.; Shamia, S.M.; Abu EL-Hamd, M.A. and Tag El-Din, M.A. (2011): Dystocia in Friesian cows and its effects on postpartum reproductive performance and milk production. Trop. Anim Health. Prod. 43:229243.

Galvoa, K.N. (2013): The main risk factors for uterine diseases are dystocia, stillbirth and prolapsed uterus. Anim. Reprod. 10:3: 228238.

Gevrekci, Y.; Chang, Y.M.; Kizilkaya, K.; Gianiola, D.; Weigel, K.A. and Akbas, Y. (2006): Bayesian interference for calving ease and stillbirth in Holstein using a bivariate threshold sire- maternal grandsire model. Abst. Book $8^{\text {th }}$ World Congress on Genetric Appl. To Liv. Prod. Brazil, Abst. 1-26, p11.

Goyache, A. and Gutierrez, J.P.(2001): Heratability of reproductive trait in Austriana di loss Valles beef cattle breed. Arch. Tierz. 44:5: 489-496.

Hafez, E. and Hafez, E.S.E. (2000): Reproduction in Farm Animals. $7^{\text {th }}$ Ed, Lippincott. Williams and Wilkins, Wolters Kluwer Com., Philadelphia.

Haskell, M.J. (2014): Dystocia in cattle: effects on the calf. Vet. Ireland. J. 4:9: 480-482.

Heringstad, B.; Chang, Y.M.; Svendson, M. and Gianola, D. (2007): Genetic analysis of calving difficulty and stillbirth in Norwegia Red cows. J. Dairy. Sci. 90: 3500-3505.

Islam, Md.H.; Sarder, Md.J.U.; Jahan, S.S.; Rahan, M.; Zahan, M.; Kader, Md.A. and Mozafford, H.K.M. (2013): Retained placenta of dairy cows associated with managemental factors in Rajshahi, Bangladesh. Vet. World. 6:4:180184.

Johanson, J.M. and Berger, P.J. (2003): Birth weight as a predictor of calving ease and perinatal mortality in Holstein cattle. J. Dairy. Sci. 86: 3745-3755.

Joosten, L.; VanEldik, P.; Elving, L. and Van der May, G.J.W. (1987): Factors related to the etiology of retained placenta in dairy cattle. Anim. Rep. Sci. 14:4:251-262.

Kaczmarowski, M.; Malinowski, E. and markiewicz, H. (2003): Risk factors of postpartum endometritis and effect of endometritis on reproductive performance in dairy cows in Korea. J. reprod. Develop., 49: 485-491.

Kaneene, J.B. and Miller, R. (1994):Epidemilogy study of metritis in Michigan dairy cattle. Vet. Res., 25: 253-257.

Laster, D.B.; Glimp, H.A.; Gundiff, I.V. and Gergory, K.I. (1973): Fctors affecting dystocia and the effects of dystocia on subsequent reproduction in beef catlle. J. Anim. Sci. 36: 676.

LeBlanc, S.T.; Duffield, T.F.; Leslie, K.E.; Bateman, K.G.; Keefe, G.P.; Walton, T.S. and Johnson, T.S. (2002): Defining and diagnosis postpartum clinical endometritis and its impact on reproductive performance in dairy cows. J. dairy Sci., 85: 2223-2236.

Lewis, G.S. (1997): Uterine health and disorders. J. Dairy Sci., 80: 984-994.

Lombard, J.E.; Garry, F.B.; Tomlinson, S.M. and Garber, L.P. (2007): Impacts of dystocia on health and survival of dairy calves. J, Dairy. Sci. 90: 1751-1760.

Markusfeld, O. (1987): Periparturient traits in seven high performance dairy herds: Incidence rate, association with parity, and interrelationships among traits. J. Dairy Sci., 70: 158-166.

McClintock, S.E. (2004): A genetic evaluation fo dystocia in Australian Holstein-Friesian cattle. $\mathrm{PhD}$, Univ, Melbourne.

McDermott, J.J.; Allen, A.B.O.; Martin, S.W. and Alves, D.M. (1992): Patterns of stillbirth and dystocia in Ontario cows- calf herds. Can. J. Vet. Res. 56: 47-55.

Mee, J.F.; Berry, D. and Cromie, A. (2011): Risk factors for calving assistance and dystocia in pasture-based Holstein-Fresian heifers and cows in Irland. The Vet. J. 187: 189-194.

Menissier, F. (1982): General survey of the effect of double muscling on cattle performance. In: Menissier, F, King, JWB. Muscle hypertrophy of genetic origin and its used to improve beef production. The Hhagu; MartinusNijhoff publisher; pp. 32-53.

Meyer, C.L.; Berger, P.J.; Koehler, K.J.; Thompson, J.R. and Sattler, C.G. (2001): Phenotype trends in incidence of stillbirth for Holstein in the United State. J. Dairy. Sci. 84: 515-523.

Newman, K.D. and Anderson, D.E. (2005): Cesarean section in cows. Vet. Clin. Food. Anim. 21: 73-100.

Noakes, D.E.; David, E.P.; Timothy, J.E. and Noakes, T.J. (2009): Veterinary Reproduction and 
Obstetrics. Parkinson, \& G.W. England (Eds.), 9th ed., Philadelphia: Saunders Ltd.

Philipsson, J. (1976): Studies on calving difficulty, stillbirth and associated factors in Swedish cattle breeds. 111. Genetic parameters. Acta. Agric. Scand. 26: 694-220.

Phocas, F and Laloe, D. (2003): Evaluation models and genetic parameters for calving difficulty in beef cattle. J. Anim. Sci. 81:933-938.

Purohit, G.N. and Mehta, J.S. (2006): Dystocia in cattle and buffaloes. A retrospective analysis of 156 cases. Vet. Practitioner. 7: 31-34.

Quass, R.L.; Zhao, Y. and Pollak, E.J. (1988): Describing interactions in dystocia scores with.a threshold model. J. Anim. Sci. 66:398.

Roberts, S.J. (1986): Veterinary obstetrics and genital diseases. $3^{\text {rd }}$ Ed., Wood Stuck. Vermont.

Sandal, W.C.D.; Curtis, R.A. and Martin, S.W. (1979): The effect of retained placenta and metritis complex on reproductive performance in dairy cattle - A case control study. Can. Vet. J., 20: 131-135.

Sheldon, I.M.; Lewis, G.S; Leblanc, S. and Gilber, R. (2006): Defining postpartum uterine disease in cattle. Theriogenology, 6: 1516-1530.

Sieber, M.; Freeman, A.E. and Kelley, D.H. (1989): Effects of body measurements and weight on calf size and calving difficulty of Holstein. J. Dairy. Sci.72: 2402-2410.

Sloss, V. (1974a): A clinical study of dystocia in catlle: 1. Treatment. Aust. Vet. J. 50:290-293.

Sloss, V. (1974b): A clinical study of dystocia in catlle: 2: Complication. Aust. Vet. J. 50: $294-$ 297.

Smith, G.F.; Laster, D.B. and Gregory, K.E. (1976): Charecterization of biological types of cattle: 1.Dystocia and preweaning growth. J. Anim. Sci. 43: 922-929.

Steinbock, L.; Nasholm, A.; Berglund, B.; Johansson, $K$. and Phlipsson, J. (2003): Genetic effects on stillbirth and calving difficulty in Swedish Holstein at first and second calving. J. Dairy. Sci.86: 2228-2235.
Thompson, J.R.; Freeman, A.E. and Berger, P.J. (1980): Relationship of dystocia transmitting ability with type and production transmiting ability in Holstein. J. Dairy. Sci. 63: 14621464.

Thompson, D.B. and Wiltbank, J.N. (1983): Dystocia in relastionship to size and shape of pelvic opening in Holstein heifers. Theriogenology. 20:6: 683-692.

Torres, B.E.; Nakao, T.; Hiramune, T.; Moriyoshi, M.; Kawata, K. and Nakada, K. (1997): Stress and uterine bacterial flora in dairy cows following clinically normal and abnormal puerperium. J. Rep, Dev., 43: 157-163.

Tripathi, A.; Mehta, J.S.; Purohit, G.S; Sharma, S.; Santi, K. and Pathak, S.K (2014): Dystocia in a cow due to hydrocephalic fetus: A case report. J. livestock Science. 5:79-82.

Uzamy, C.; Kaya, I. and Ayyilmaz, I. (2010): Analysis of risk factors for dystocia in a Turkish Holstein herd. J. Anim. Vet. Advance. 9: 2571-2577.

Vaughan, L. and Mulville, P. (1995): A survey of bovine cesarean section in the cows. Vet. Clin. North. Am. Food. Anim. Pract9. 5:11: 19-35.

Wehrend, A.; Reinic, T.; Herfen, K. and Bostedt, H. (2002): Fetotomy in cattle with special reference to postoperative complications anevaluation of 131 cases. Dtach. Tierarzt. Wochenschr. 109:56-61.

Youngquist, R.S. and Shore, M.D. (1997): Postpartum uterine infection. In: Youngquist, R.S., $1^{\text {st }}$ Ed., Current Therapy in Large Animal Theriogenology, W.B. Saunders Com., Philadelphia. PP: 335-340.

Zaborski, D.; Grzesiak, W. and Szatkowska, I. (2009): Factors affecting dystocia in cattle Reprod. Dom. Anim. 44: 540-551.

Zhang, W.C.; Nakao, T. and Moriyoshi, M. (1999): Relationship of maternal plasma progesterone and estrone sulfate to dystocia in Holstein Friesian heifers and cows. J. Vet. Med. Sci. 61, 909-913.

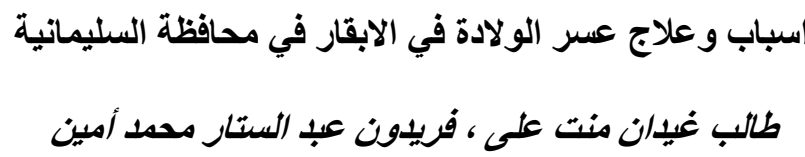

E-mail:talib_1960@yahoo.comAssiut University web-site: www.aun.edu.eg

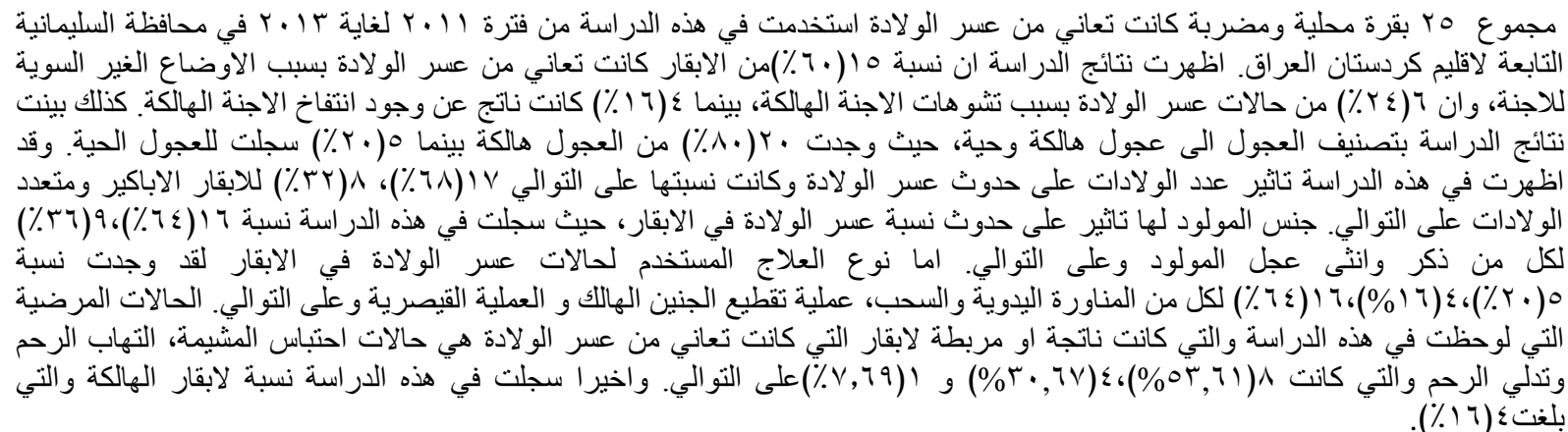

